Supplement of Adv. Geosci., 45, 105-113, 2018

https://doi.org/10.5194/adgeo-45-105-2018-supplement

(C) Author(s) 2018. This work is distributed under

the Creative Commons Attribution 4.0 License.

(c) (1)

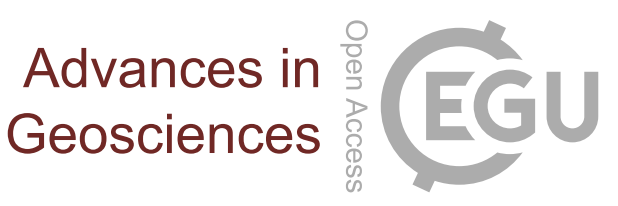

Supplement of

\title{
Carbon in global waste and wastewater flows - its potential as energy source under alternative future waste management regimes
}

Adriana Gómez-Sanabria et al.

Correspondence to: Adriana Gómez-Sanabria (gomezsa@iiasa.ac.at)

The copyright of individual parts of the supplement might differ from the CC BY 4.0 License. 


\section{Table of Contents}

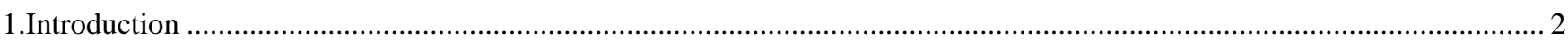

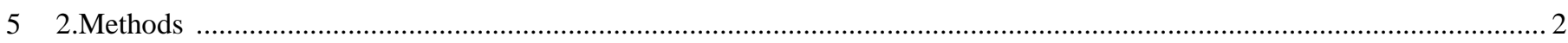

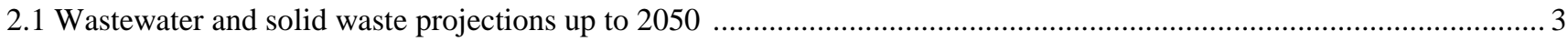

2.2 Carbon content determination and energy calculations .................................................................................... 10

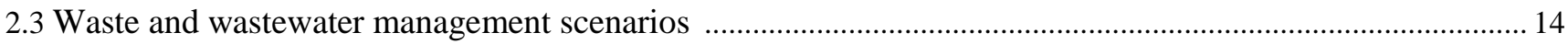

2.4 Limitations and uncertainty of the waste and wastewater management scenarios …..................................... 16

10

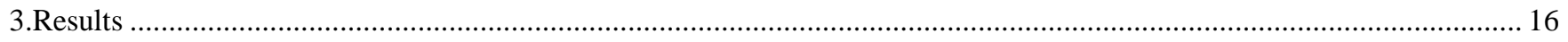

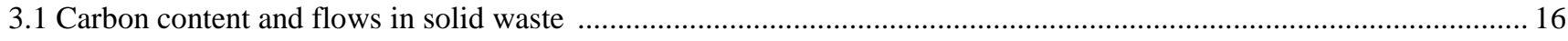

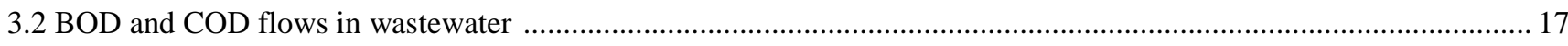

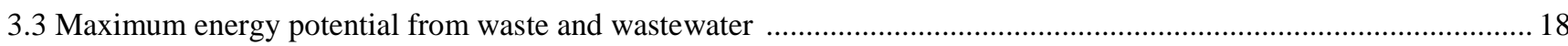

15 


\section{S1 Introduction}

The information presented here is intended to extend and provide more detailed information on the projections of waste and wastewater (COD and BOD content) generation, underlying assumptions, and data sources used.

\section{S2 Methods}

5 Key assumptions for calculations of waste carbon content and potentials for biogas and energy-recovery are presented in Table S1.

Table S1. Key assumptions to determine carbon content and energy generation

\begin{tabular}{|c|c|c|c|}
\hline Activity & Variable & Description/assumption & Reference \\
\hline Solid waste & Maximum carbon conversion & $\begin{array}{l}77 \% \text { of total organic carbon } \\
\text { available is decomposed }\end{array}$ & IPCC, 2006 \\
\hline Organic waste & Waste conversion rate to biogas & $150 \mathrm{~m} 3$ biogas $\mathrm{kg}^{-1}$ waste & Kigozi et al., 2014 \\
\hline Manure & Water content of manure & $85 \%$ water content & Höglund-Isaksson, 2015 \\
\hline Manure & Manure conversion rate to biogas & $\begin{array}{l}33.53 \mathrm{~m} 3 \text { ton }^{-1} \text { manure when } \\
\text { manure is co-digested }\end{array}$ & Based on IEA, 2014 \\
\hline $\begin{array}{l}\text { Co-digestion }(80 \% \text { manure }+ \\
20 \% \text { organic waste) }\end{array}$ & $\begin{array}{l}\text { Wet substrate conversion rate to } \\
\text { energy }\end{array}$ & $380 \mathrm{KWh} /$ ton wet substrate & Höglund-Isaksson, 2015 \\
\hline $\begin{array}{l}\text { Co-digestion }(80 \% \text { manure }+ \\
20 \% \text { organic waste) }\end{array}$ & $\begin{array}{l}\text { Waste conversion rate to biogas } \\
\text { co-digestion }\end{array}$ & $65.295 \mathrm{~m} 3$ ton -1 & Höglund-Isaksson, 2015 \\
\hline Biogas & $\begin{array}{l}\text { Biogas from anaerobic digestion } \\
\text { composition }\end{array}$ & $60 \% \mathrm{CH} 4+40 \% \mathrm{CO} 2$ & IPCC, 2006 \\
\hline Landfill gas & Landfill gas composition & $50 \% \mathrm{CH} 4+50 \% \mathrm{CO} 2$ & Spokas et al., 2006 \\
\hline Landfill gas & Gas efficiency collection rate & $60 \%$ & Spokas et al., 2006 \\
\hline Biogas & $\begin{array}{l}\text { Energy from biogas (before } \\
\text { conversion) }\end{array}$ & $6.1 \mathrm{kWh} \mathrm{m}^{-3}$ biogas & de Mes et al., 2003 \\
\hline Biogas & Biogas thermal value & $22 \mathrm{MJ} \mathrm{m}^{-3}$ biogas & Spokas et al., 2006 \\
\hline Biogas & Biogas density & $1.132 \mathrm{~kg} \mathrm{~m}-3$ & Karellas et al., 2010 \\
\hline \multirow{7}{*}{$\begin{array}{l}\text { Incineration solid waste (Low } \\
\text { Heating value- LHV) }\end{array}$} & Food waste & $5.5 \mathrm{MJ} \mathrm{Kg}^{-1}$ & Noukeu et al., 2016 \\
\hline & Plastic waste & $27.8 \mathrm{MJ} \mathrm{Kg}^{-1}$ & \multirow{6}{*}{ Consonni and Viganò, 2011} \\
\hline & Paper waste & $16.20 \mathrm{MJ} \mathrm{Kg}^{-1}$ & \\
\hline & Wood waste & $18.84 \mathrm{MJ} \mathrm{Kg}^{-1}$ & \\
\hline & Textile waste & $19.88 \mathrm{MJ} \mathrm{Kg}^{-1}$ & \\
\hline & Rubber waste & $22.5 \mathrm{MJ} \mathrm{Kg}^{-1}$ & \\
\hline & Other waste & $5.69 \mathrm{MJ} \mathrm{Kg}^{-1}$ & \\
\hline Industrial wastewater & COD conversion rate to biogas & $0.35 \mathrm{~m} 3$ biogas $\mathrm{kg}^{-1} \mathrm{COD}$ & de Mes et al., 2003 \\
\hline Industrial wastewater & $\begin{array}{l}\text { Maximum methane production } \\
\text { capacity }\end{array}$ & $0 . .25 \mathrm{~kg} \mathrm{CH}_{4} \mathrm{Kg} \mathrm{COD}$ & IPCC, 2006 \\
\hline Industrial wastewater & Effluent untreated temperature & $30^{\circ} \mathrm{C}$ & Noukeu et al., 2016 \\
\hline Domestic wastewater & COD conversion rate to biogas & $0.84 \mathrm{~m} 3$ biogas $\mathrm{kg}^{-1} \mathrm{COD}$ & de Mes et al., 2003 \\
\hline Domestic wastewater & $\begin{array}{l}\text { Country specific per capita BOD } \\
\text { taken from IPCC Guidelines } 2006\end{array}$ & $\mathrm{BOD}_{5}$ & $\begin{array}{l}\text { IPCC, 2006. Volume 5. Waste, } \\
\text { Table } 6.4\end{array}$ \\
\hline Domestic wastewater & BOD conversion rate to biogas & $0.84 \mathrm{~m} 3$ biogas $\mathrm{kg}^{-1}$ BOD & $\begin{array}{l}\text { IPCC, 2006Volume 5. Waste, } \\
\text { Table } 6.2\end{array}$ \\
\hline Methane solubility in wastewater & Methane solubility & $45 \%$ of $\mathrm{CH}_{4}$ produced at $30^{\circ} \mathrm{C}$ & Liu et al., 2014 \\
\hline Primary treatment & COD/BOD removal efficiency & $35 \%-40 \%$ & Cakir and Stenstrom, 2005 \\
\hline Anaerobic treatment & COD/BOD removal efficiency & $80 \%$ & Cakir and Stenstrom, 2005 \\
\hline
\end{tabular}




\section{S2.1 Wastewater and solid waste projections up to 2050}

Industrial solid waste: Table S2 presents industrial waste generation by income group classification (see Table S5) and type of manufacturing industry type.

Table S2. Total industrial waste generation in 2010 in Mt

\begin{tabular}{|c|c|c|c|c|c|c|c|c|}
\hline $\begin{array}{l}\text { Income } \\
\text { group }\end{array}$ & $\begin{array}{c}\text { Food } \\
\text { industry }\end{array}$ & $\begin{array}{l}\text { Pulp and } \\
\text { paper } \\
\text { industry }\end{array}$ & $\begin{array}{l}\text { Rubber } \\
\text { industry }\end{array}$ & $\begin{array}{c}\text { Textile } \\
\text { industry }\end{array}$ & $\begin{array}{c}\text { Wood } \\
\text { industry }\end{array}$ & $\begin{array}{c}\text { Other } \\
\text { manufacturing } \\
\text { industry }\end{array}$ & Total & Reference \\
\hline Low & 161 & 16 & 3 & 9 & 19 & 958 & 1167 & \\
\hline Middle low & 154 & 19 & 12 & 6 & 36 & 1171 & 1398 & Höglund- \\
\hline Middle & 14 & 3 & 1 & 3 & 3 & 79 & 103 & Isaksson, 2012 \\
\hline Middle high & 23 & 13 & 13 & 2 & 4 & 78 & 133 & Eurostat, 2017, \\
\hline High & 103 & 98 & 47 & 7 & 59 & 338 & 651 & OECD, 2017 \\
\hline World & 455 & 149 & 76 & 26 & 121 & 2624 & 3452 & \\
\hline
\end{tabular}

Municipal solid waste - Description of data and variables used to estimate waste generation elasticities: The dataset for EU28 countries and some OECD countries covers between 17 and 19 years. For the rest of the countries, the dataset covers between 4 and 10 years. In total, the unbalanced panel data set comprises 684 observations. Data on municipal solid waste generation

10 in kilogram per capita are obtained from different sources (see Table S3). In order to control for the influence of population growth, waste generation per capita is chosen instead of total waste generation as dependent variable in elasticity estimations (Lebersorger and Beigl, 2011). All variables are specified in logarithmic form in order to provide parameter estimates that can be directly interpreted as elasticity values.

15 
Table S3.Dataset description

\begin{tabular}{lcl}
\hline \multicolumn{1}{c}{ Country } & Years & \multicolumn{1}{c}{ Waste generation data - Source } \\
\hline EU 28 countries & $1995-2012$ & Eurostat (retrieved 2016) \\
Japan & $1995-2013$ & OECD (retrieved 2016) \\
Norway & $1995-2014$ & OECD (retrieved 2016) \\
Colombia & $2003-2011$ & SSPD 2011 \\
Israel & $2001-2013$ & OECD (retrieved 2016) \\
Mexico & $1995-2012$ & OECD (retrieved 2016) \\
Turkey & $1995-2013$ & OECD (retrieved 2016) \\
Serbia & $2006-2013$ & Eurostat (retrieved 2016) \\
Macedonia & $2008-2014$ & Eurostat (retrieved 2016) \\
Malaysia & $1996-2000$ & Department of statistics Malaysia (accessed 2016) \\
Kenya & $1998-2009$ & \\
Montenegro & $2008-2013$ & Eurostat (retrieved 2016) \\
Bosnia and Herzegovina & $2008-2013$ & Eurostat (retrieved 2016) \\
Australia & $2006-2011$ & OECD (retrieved 2016) \\
Switzerland & $1995-2013$ & OECD (retrieved 2016) \\
Peru & $2012-2015$ & Municipalidad Metropolitana de Lima (MML) \\
& & 2015 \\
\hline
\end{tabular}

In terms of explanatory variables (see Table S4), generation of waste has primarily been linked to economic growth and increases in population and urbanization (Johnstone and Labonne, 2004; Mazzanti and Nicolli, 2011; Mazzanti and Zoboli, 5 2008, 2009). Income is a major driver of municipal waste generation (Mazzanti and Zoboli, 2008). Gross domestic product has been widely used as the economic parameter to project waste generation (Daskalopoulos et al., 1998). 
Table S4. List of variables

\begin{tabular}{|c|c|c|c|c|c|c|}
\hline Variable & Definition & Source & Mean & $\begin{array}{l}\text { Standard } \\
\text { Deviation }\end{array}$ & Minimum & Maximum \\
\hline \multicolumn{7}{|c|}{ Dependent Variable } \\
\hline MSW & $\begin{array}{l}\text { Municipal solid waste generated } \\
\text { Kg per person per year }\end{array}$ & See Table S2 & 383.71 & 113.82 & 101.1 & 667 \\
\hline \multicolumn{7}{|c|}{ Explanatory Variables } \\
\hline GDP & $\begin{array}{l}\text { Gross domestic product } \\
\text { USdollar2010 per person per year }\end{array}$ & $\begin{array}{l}\text { World Bank (accessed } \\
\text { 2016) }\end{array}$ & 28517.61 & 20440.94 & 4945.95 & 110001.1 \\
\hline UR & $\begin{array}{l}\text { Average Annual Rate of Change } \\
\text { of the Percentage Urban by Major } \\
\text { Area, Region and Country }\end{array}$ & $\begin{array}{l}\text { United Nations -world } \\
\text { populations prospects } \\
\text { (2014) }\end{array}$ & 71.01 & 13.17 & 19 & 97.73 \\
\hline
\end{tabular}

Elasticity estimation models: Historical data on municipal solid waste generation per capita (dependent variable) are plotted

5 against GDP per capita (independent variable) in order to visualize the relationship between the two variables and to identify possible clusters of municipal waste generation (Fig. S1).

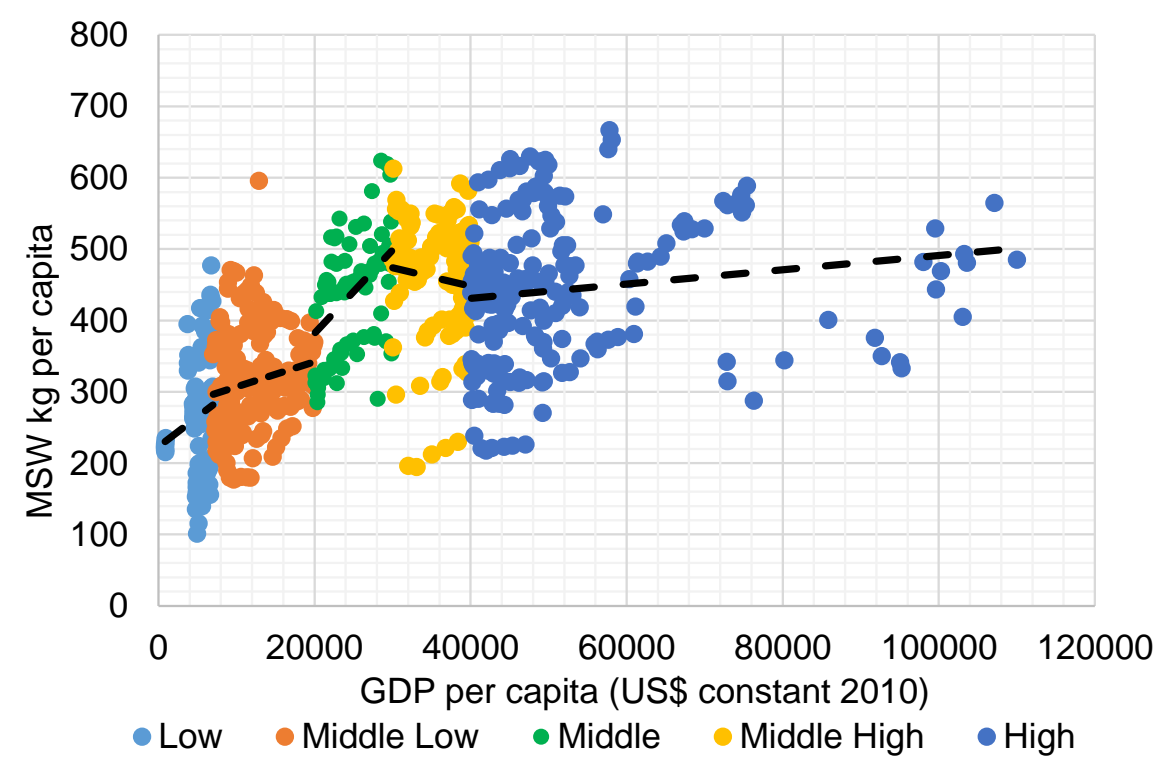

Fig. S1. Municipal solid waste vs GDP per cap.

10 The definition of the different income groups was carried out based on the distribution of the scatterplot. Table S5 shows the countries belonging to each of the five income groups in 2010 (which is the base year for the projections). Note that in the subsequent projections, countries may over time move out of their initial income group and into a higher income group 
following an increase in the GDP per capita consistent with the macroeconomic scenario of the IEA World Energy Outlook

2017 (IEA, 2017). Hence, the group distribution of the municipal solid waste generation is dynamic over time.

Table S5. Country by income group in base year 2010

\section{Income group Country/region}

High

Middle - High

Middle

Middle - Low

Low
Austria, Australia, Belgium, Canada, China (Hong Kong and Macau), Denmark, Finland, France, Germany, Iceland, Ireland, Japan (Chugoku Shikoku, Chubu, Hokkaido-Tohoku, Kanto, Kinki), Luxembourg, Netherlands, Norway, Sweden, Switzerland and United States of America.

Brunei, Israel, Italy, Japan (Kyushu Okinawa), South Korea (Busan), New Zealand, Singapore, Spain and United Kingdom.

Cyprus, Greece, South Korea (Seoul - Inchon, South region), Malta, Portugal, Slovenia and Taiwan.

Argentina, Caribbean (includes countries in the Caribbean region), Chile, China (Shanghai), Croatia, Czech Republic, Estonia, Hungary, Iran, South Korea (North region), Latvia, Lithuania, Malaysia (Peninsular Malaysia), Mexico, North Africa (includes Algeria, Morocco, Libya, Tunisia, Sudan), Poland, Romania, Russia (Europe and Asia), Saudi Arabia, Slovak Republic, Turkey and Uruguay.

Afghanistan, Albania, Armenia, Azerbaijan, Bangladesh (Dhaka and rest of Bangladesh), Belarus, Bhutan, Bosnia and Herzegovina, Bolivia, Brazil, Bulgaria, Cambodia, Central America, China (Anhui, Beijing, Chongqing, Fujian, Gansu, Guangdong, Guangxi, Guizhou, Hainan, Hebei, Heilongjiang, Henan, Hubei, Hunan, Jilin, Jiangsu, Jiangxi, Liaoning, Inner Mongolia, Ningxia, Qinghai, Shaanxi, Sichuan, Tianjin, Tibet, Xinjiang, Yunnan and Zhejiang), Colombia, Ecuador, Egypt, Former Soviet Union States (includes Tajikistan, Turkmenistan and Uzbekistan), Georgia, India (Andhra Pradesh, Assam, West Bengal, Bihar, Chhattisgarh, Delhi, North East (excl Assam), Goa, Gujarat, Haryana, Himachal Pradesh, Jharkhand, Karnataka, Kerala, Maharashtra, Manipur, Orissa, Punjab, Rajasthan, Tamil Nadu, Uttarakhand, Uttar Pradesh, Jammu Kashmir), Indonesia (Jakarta, Java Sumatra and rest of Indonesia), Kazakhstan, North Korea, Kosovo, Kyrgyzstan, Laos, Macedonia, Malaysia (Sarawak Sabah and Kuala Lumpur), Iran, Moldova, Mongolia, Montenegro, Myanmar, Nepal, Other African countries (includes all other African countries), Pakistan (Karachi, NW frontier provinces Baluchistan, Punjab and Sindh), Paraguay, Peru, Philippines (Bicol, Luzol and Manila), South Africa, Serbia, Sri Lanka, Thailand ( Bangkok, Central Valley, North Eastern Plateau, Northern Highlands and Southern Peninsula), Ukraine, Venezuela and Vietnam (North and South).

5 The panel data analysis is performed to determine the elasticity of the different variables on the generation of municipal solid waste per capita. Pooled OLS, fixed effects and random effects estimator models are run to test the effects of the explanatory variables on municipal waste generation per capita. In the pooled models a single slope is calculated for all countries and the between (cross-sectional) and within (time) variances are bluntly added up. When the cross-sectional variance is eliminated and the slopes are based on time variance only, the model is denoted a within estimator whereas in between models the time variance is eliminated and only cross-sectional variance is considered in the elasticity parameter. In fixed effect models, the within estimator is describing the slope while the country-specific effects are captured as country-specific constants. Finally, 
random effect model treats the individual effects as random variables and the variance is a weighted average of within and between variance (Hsiao, 1986). Three different tests are applied to select the appropriate model. A Lagrange Multiplier (LM) test is applied to test for the cross-sectional dependence in heterogeneous panels (test random effects vs pooling). An F test is used to test for individual effects based on the comparison between the within and the pooling model and a Hausman test is

5 used to evaluate the difference in vector coefficients between the fixed and random effects models. Here, we explore the possible effects of the explanatory variables on municipal solid waste generation and we test the hypothesis that there are no individual effects, against that there are individual effects. In order to test for a potential presence of homogeneity a Bartlett test is conducted. The Bartlett test is used to test if groups or samples have equal variances, however, the test is sensitive to normality. Therefore, two tests that are less sensitive to normality such as the Chi-square test and Fligner-Killen test are conducted as well (Table S6).

Table S6. Test homogeneity of variances

\begin{tabular}{cccc}
\hline Test & Hypothesis & Results & Ho \\
\hline Barlest test & Ho: $\sigma_{0}^{2}=\sigma_{1}^{2}=\cdots \sigma_{\mathrm{k}}^{2}$ & $29.407^{* * * *}$ & Rejected \\
& Ho: $\sigma_{0}^{2} \neq \sigma_{1}^{2}$ & & \\
Chi square test & Ho: $\sigma^{2}=\sigma_{0}^{2}$ & & Rejected \\
& Ha: $\sigma^{2} \neq \sigma_{0}^{2}$ & $9.48^{* * *}$ & \\
Fligner-Killeen & Ho: $\sigma^{2}=\sigma_{0}^{2}$ & & Rejected \\
\hline
\end{tabular}

The results of the elasticity estimations of municipal solid waste generation to GDP per capita and urbanization rate and the functions for waste generation projections are presented in Table S7. The LM test favoured in all cases the random effect over

15 the OLS model, meaning that there is evidence of significant differences across countries. F test for individual effects favoured always the fixed effect model over the OLS, which means that the fixed effect are non-zero and finally, the Hausman test rejected the random effect model, which assume that the slope coefficients of the two models do not differ and it favoured the fixed effect model. Furthermore, due to the fact that waste composition influences energy generation, projections of waste compositions are relevant. In particular, low income countries tend to have a considerably higher fraction of food waste in the

20 total municipal waste generated than high income countries. Therefore, changes in the future composition of waste are projected based on an estimated elasticity of food waste generation to GDP per capita. Due to limited access to historical data on food waste generation, the elasticity is estimated from a sample of 156 observations of in an unbalanced panel. A fixed effects model was favoured on the basis of Hausman test as the better explanatory model with a resulting elasticity of food waste generation to GDP per capita of 0.42 (Table S7). 
Table S7. MSW generation elasticities to GDP and Urbanization rate

\begin{tabular}{|c|c|c|c|c|c|c|c|c|c|}
\hline $\begin{array}{c}\text { Dependent } \\
\text { Variable }\end{array}$ & Unit & $\begin{array}{c}\text { Income group (U\$ } \\
\text { dollars per capita } \\
\text { year) }\end{array}$ & $\begin{array}{c}\text { Number of } \\
\text { obs ervatio } \\
\text { ns }\end{array}$ & $\begin{array}{c}\text { Explanatory } \\
\text { variable }\end{array}$ & OLS & Fixed Effect & Random Effect & LM - test & Hausman -test \\
\hline \multirow{24}{*}{$\begin{array}{l}\text { Municipal } \\
\text { solid } \\
\text { waste }\end{array}$} & \multirow{24}{*}{$\begin{array}{l}\text { Kt per } \\
\text { capita }\end{array}$} & $<7000$ & 98 & Constant & $4.96(10.50) * * *$ & n.a & $2.44(3.97)^{* * *}$ & 84.92 & 3.66 \\
\hline & & & & GDP per capita & $0.06(1.21)$ & $0.41(5.38) * * *$ & $0.36(5.04) * * *$ & & \\
\hline & & & & Urbanization rate & & & & & \\
\hline & & & & R-square & 0.01 & 0.25 & n.a & & \\
\hline & & $>=7000-<20000$ & 193 & Constant & $4.15(8.42)^{* * *}$ & n.a & $3.68(6.96)^{* * *}$ & 38.22 & 0.002 \\
\hline & & & & GDP per capita & $0.16(3.19)^{* *}$ & $0.22(3.73) * * *$ & $0.21(3.92)^{* * *}$ & & \\
\hline & & & & Urbanization rate & & & & & \\
\hline & & & & R-square & 0.05 & 0.07 & n.a & & \\
\hline & & $>=20000-<30000$ & 75 & Constant & $-0.92(-0.56)$ & n.a & $-0.35(-0.23)$ & 21.99 & 0.001 \\
\hline & & & & GDP per capita & $0.69(4.30)^{* * *}$ & $0.62(4.23) * * *$ & $0.62(4.30) * * *$ & & \\
\hline & & & & Urbanization rate & & & & & \\
\hline & & & & R-square & 0.20 & 0.21 & n.a & & \\
\hline & & $>30000-<40000$ & 108 & Constant & $5.98(2.23)^{*}$ & n.a & $2.82(1.53)$ & 140.56 & 20.93 \\
\hline & & & & GDP per capita & $-0.16(-0.68)$ & $0.80(7.31)^{* * *}$ & $0.55(5.40)$ & & \\
\hline & & & & Urbanization rate & $0.43(2.01)^{*}$ & $-3.27(-4.43) * * *$ & $-0.60(-1.33)^{* * *}$ & & \\
\hline & & & & R-square & 0.04 & 0.37 & n.a & & \\
\hline & & $>=40000$ & 210 & Constant & $3.33(3.72) * * *$ & $\mathrm{n} . \mathrm{a}$ & $-0.10(-0.07)$ & 52.22 & 17.43 \\
\hline & & & & GDP per capita & $0.17(2.55)^{*}$ & $1.07(8.20) * * *$ & $0.84(7.10) * * *$ & & \\
\hline & & & & Urbanization rate & $0.18(1.38)$ & $-1.28(-3.66) * * *$ & $-0.67(-2.28)^{*}$ & & \\
\hline & & & & R-square & 0.043 & 0.26 & n.a & & \\
\hline & & All income groups & 684 & Constant & $3.85(21.10) * * *$ & n.a & $4.03(8.61)^{* * *}$ & & \\
\hline & & & & GDP per capita & $0.24(17.51)^{* * *}$ & $0.43(13.13)^{* * *}$ & $0.37(13.72) * * *$ & 95.64 & 10.45 \\
\hline & & & & Urbanization rate & $-0.08(-1.52)$ & $-0.45(-2.27)^{*}$ & $-0.43(-3.42)^{* * *}$ & & \\
\hline & & & & R-square & 0.4 & 0.21 & n.a & & \\
\hline \multirow{3}{*}{$\begin{array}{l}\text { Food } \\
\text { waste }\end{array}$} & \multirow{3}{*}{$\begin{array}{l}\text { Kt per } \\
\text { capita }\end{array}$} & All income groups & 156 & Constant & $4.05(9.32)^{* * *}$ & n.a & $2.78(4.29)^{* * *}$ & & \\
\hline & & & & GDP per capita & $0.05(1.33)$ & $0.42(4.22) * * *$ & $0.18(2.85)^{* *}$ & 40.54 & 9.78 \\
\hline & & & & R-square & 0.01 & 0.12 & n.a & & \\
\hline
\end{tabular}

Where:, $\varepsilon_{i t}=u_{i}+v_{i t}$ is an error term which is separated into an individual effects term and a residual omitted variables term, and $\varepsilon_{i t} \sim I I D\left(0, \sigma_{\varepsilon}^{2}\right)$ is an error

5 term which are assumed to be normally distributed with mean zero and constant variance.

Although, there are more availability of data for developed countries, it was possible to find a limited set of about ten developing countries for which enough information was available to include in the estimation of elasticities of municipal solid waste generation to GPD per capita and urbanization rates. However, due to a general lack of data from developing countries

10 on food waste generation, the elasticity estimates for food waste generation are based on data from Eurostat (2016) and cover mainly developed countries. In addition, only GDP per capita and changes in the urbanization rate are used as explanatory variables. In reality, many more factors are likely to influence the generation of municipal waste, in particular household- 
specific factors e.g., household size, type of dwellings, rural or urban, income distribution, etc. It would have been desirable to conduct the elasticity estimations at a more disaggregated level, representing the diverse circumstances within a country, however, this was not possible due to limitations in data availability.

Table S8 presents municipal waste generation rates and composition for the year 2010 (base year for projections). Since yearly

5 information on waste composition is limited (especially for developing countries), the most recent available data is used.

References apply to the waste management data as well.

Table S8. Municipal solid waste generation and composition in 2010.

\begin{tabular}{|c|c|c|c|c|c|c|c|c|c|c|c|c|}
\hline \multirow{2}{*}{$\begin{array}{l}\text { Income } \\
\text { group }\end{array}$} & \multirow{2}{*}{$\begin{array}{l}\text { No. of } \\
\text { count } \\
\text { ries/re } \\
\text { gions }\end{array}$} & \multicolumn{3}{|c|}{ Municipal solid waste generation } & \multicolumn{8}{|c|}{ Composition (weighted average across countries) } \\
\hline & & $\begin{array}{c}\text { Mt } \\
\text { year }^{-1}\end{array}$ & $\begin{array}{c}\text { Kg cap }^{-1} \\
\text { day }^{-1}\end{array}$ & $\begin{array}{l}\text { Range Kg } \\
\text { cap }^{-1} \text { day }^{-1}\end{array}$ & Food & Paper & Plastic & Glass & Metal & Wood & Textile & Other \\
\hline Low & 112 & 1249 & 0.67 & $0.06-1.94$ & 0.51 & 0.09 & 0.09 & 0.03 & 0.02 & 0.06 & 0.04 & 0.17 \\
\hline Middle low & 23 & 246 & 0.87 & $0.16-1.51$ & 0.44 & 0.16 & 0.09 & 0.07 & 0.02 & 0.06 & 0.03 & 0.12 \\
\hline Middle & 8 & 31 & 1.03 & $0.85-1.54$ & 0.31 & 0.24 & 0.12 & 0.05 & 0.05 & 0.07 & 0.03 & 0.14 \\
\hline Middle high & 9 & 107 & 1.40 & $0.78-1.90$ & 0.29 & 0.25 & 0.13 & 0.06 & 0.03 & 0.02 & 0.03 & 0.19 \\
\hline High & 22 & 456 & 1.77 & $0.80-2.19$ & 0.25 & 0.30 & 0.13 & 0.06 & 0.07 & 0.05 & 0.05 & 0.10 \\
\hline World & 174 & 2088 & 0.83 & $0.06-2.19$ & 0.43 & 0.15 & 0.10 & 0.04 & 0.03 & 0.06 & 0.04 & 0.15 \\
\hline
\end{tabular}

10 Source: Low: Forouhar and Hristovski, 2012, Wiedinmyer et al., 2014, Hoornweg and Bhada-Tata, 2012, Arzumanyan, 2014, Anon, 2009; Bhuiyan, 2010; Zakir Hossain et al., 2014, Penjor, 2007, Viceministerio de agua potable, 2012, Castagnari, 2005, Eurostat 2016, Ministry of Environment PNH, 2010; Mongtoeun, 2015, Bo-Feng et al., 2014; China Statistical Yearbook, 2007; Wang and Nie, 2001, Larochelle et al., 2012; Martínez, 2015, M. Sim et al., 2013, Kumar et al., 2009; Sharholy et al., 2008, Damanhuri et al., 2009; Meidiana and Gamse, 2010; Pasang et al., 2007, Vermenchiva et al., 1999, Sang-Arun and Pasomsouk, 2012, Cvetkovska and Rushiti, 2013, Budhiarta et al., 2012;

15 Manaf et al., 2009, agath P and Hengesbaugh, 2016, Viraraghavan, 2005, Bello et al., 2016; Parrot et al., 2009, Mahar et al., 2007, Organización Panamericana de la Salud, 2001, Department of Environmental Affairs, 2012, ISWA, 2011; Vukmirovic, 2012, Hikkaduwa et al., 2015; Karunarathne, 2015, Tanakwang and Tangtinthai, 2010, International Finance Corporation, 2010, Instituto Nacional de Estadística, 2012, Nguyen, 2005, Thang, 2011.

Middle low: Gonzalez, 2010; Savino, 1999, Hoornweg and Bhada-Tata, 2012, Bräutigam and Gonzalez, n.d.), Bo-Feng et al., 2014; China

20 Statistical Yearbook, 2007; Wang and Nie, 2001, Eurostat 2016, Alavi Moghadam et al., 2009; Damghani et al., 2008, Ryu, 2010, Budhiarta et al., 2012; Manaf et al., 2009, Gomez et al., 2008, Bello et al., 2016; Okot-Okumu, 2012; Parrot et al., 2009; SWEEPNET, 2012,

Middle: Eurostat 2016, Chieueh and Yu, 2006; Tsai and Chou, 2006

Middle High: Wiedinmyer et al., 2014, Ministry of environmental protection, 2012, Eurostat 2016, OECD, 2016 ;Ministry of the Environment, 2012, ISWA, 2011, Bai and Sutanto, 2002, Burnley, 2007; Daskalopoulos et al., 1998

25 High: Eurostat 2016, Asase et al., 2009, Bo-Feng et al., 2014; China Statistical Yearbook, 2007; Wang and Nie, 2001, OECD, 2016 ;Ministry of the Environment, 2012, EPA, 2012

\section{S2.2 Carbon content determination and energy calculations}

\section{S2.2.1 Solid waste}

30 In order to quantify the carbon content of industrial and municipal solid waste and the respective flows, the following approach is used (calculations are always carried out by region for the 174 countries/regions and with annual results presented for every five years): 
1. Quantification of DOC and FC in municipal and industrial solid waste using IPCC default values for DOC and FC (IPCC, 2006, Volume 5, Chapter 2).

2. Identification by country/region of the application rate of current (and future) waste management technologies/systems (EUROSTAT 2016, OECD 2016, UNFCCC CRF Tables 2016 and documents referenced in Table S8 supplement material). This study distinguishes various management options for each of the solid waste fractions. Description of each of the options can be found in Table S8. The assessment of the carbon flows is then carried out applying Eq. (S1). and Eq. (S2):

$$
\operatorname{DOC}_{m, s ; j}=\mathrm{W}_{\mathrm{s}, \mathrm{j}} * \mathrm{DMC}_{\mathrm{s}, \mathrm{j}} * \operatorname{DOCd}_{\mathrm{s}, \mathrm{j}} * \operatorname{Appl}_{\mathrm{m}, \mathrm{s}, \mathrm{j}} * 0.01 \quad \text { Eq. (S1) } \quad ; \quad \mathrm{FC}_{\mathrm{m}, \mathrm{s} ; \mathrm{j}}=\mathrm{W}_{\mathrm{s}, \mathrm{j}} * \mathrm{FCC}_{\mathrm{s}, \mathrm{j}} * \mathrm{Appl}_{\mathrm{m}, \mathrm{s}, \mathrm{j}} * 0.01 \quad \text { Eq. (S2) }
$$

10

Where: $\mathrm{DOC}_{\mathrm{m}, \mathrm{s}, \mathrm{j}} / \mathrm{FC}_{\mathrm{m}, \mathrm{s} ; \mathrm{j}}$ is the amount of Degradable Organic Carbon (DOC)/ Fossil Carbon (FC) in dry waste type $\mathrm{j}$ in sector $\mathrm{s}$ (municipal/industrial) going to a specific treatment $\mathrm{m} ; \mathrm{W}_{\mathrm{s}, \mathrm{j}}$ is the amount of waste type $\mathrm{j}$ generated in sector $\mathrm{s}$ (municipal/industrial); $\mathrm{DMC}_{\mathrm{s}, \mathrm{j}}$ is the Dry Matter Content (DMC) in $\%$ of wet waste $\mathrm{j}$ generated in sector $\mathrm{s}$ (municipal/industrial); DOCd $_{s, j}$ is the DOC in \% of dry waste $\mathrm{j}$ generated in sector s (municipal/industrial); $\mathrm{FCC}_{\mathrm{s}, \mathrm{j}}$ is the 15 fraction of Fossil Carbon in \% of Total Carbon in waste $\mathrm{j}$ generated in sector s (municipal/industrial) and $\mathrm{Appl}_{\mathrm{m}, \mathrm{s}, \mathrm{j}}$ is the application of the waste treatment option $\mathrm{m}$ to waste type $\mathrm{j}$ generated in sector $\mathrm{s}$ (municipal/industrial).

3. Estimation of energy recovery from municipal and industrial solid waste: This study identifies anaerobic digestion, landfill with gas recovery and use and waste incineration as the three main treatment technologies to convert waste into a source of energy.

Anaerobic digestion: Biogas generation is calculated using Eq. (S3) from Höglund-Isaksson, 2015 and Eq. (S4) :

$$
\mathrm{BCD}=\left(\mathrm{TS} * \mathrm{Y}_{\mathrm{cd}}\right) \quad \text { where } \quad \mathrm{TS}=\operatorname{MaxM}+\left(\frac{\mathrm{MaxM} * 100}{80}\right) * 0.2 \quad \text { Eq. }(\mathrm{S} 3) \quad ; \quad \mathrm{BSS}=\left(\mathrm{S} * \mathrm{Y}_{\mathrm{o}, \mathrm{m}}\right) \text { Eq. }(\mathrm{S} 4)
$$

25 Where: $\mathrm{BCD}$ is biogas from co-digestion; TS is total substrate; $\mathrm{Y}_{\mathrm{cd}}$ is the biogas yield of co-digestion when $80 \%$ manure $20 \%$ organic waste ; MaxM is the maximum manure available for co-digestion; BSS is the biogas single substrate; $\mathrm{S}$ is the substrate and $; \mathrm{Y}_{\mathrm{o}, \mathrm{m}}$ is the biogas yield when digestion only organic waste or only manure.

Landfill: Landfill gas generation is accounted for with a lag of 10 years for fast degrading organic waste and 20 years for slow 30 degrading waste. Landfill gas generation is calculated using Eq. (S5) based on (IPCC, 2006, Volume 5, Chapter 2 and Chapter 3):

$$
\mathrm{LG}=\left(\left(\mathrm{DOC}_{\mathrm{s} ; \mathrm{j}} * 0.77 * \mathrm{~F} * 16 / 12\right)+\left(\mathrm{DOC}_{\mathrm{m}, \mathrm{s} ; \mathrm{j}} * 0.77 * \mathrm{~F} * 44 / 12\right)\right) * 0.60 * 1 / 1.132 \quad \text { Eq. (S5) }
$$


Where: LG is landfill gas; DOC $_{s ; j}$ is the amount of Degradable Organic Carbon (DOC) in dry waste type $\mathrm{j}$ in sector $\mathrm{s}$ (municipal/industrial) going to landfills with gas recovery; 0.77 is the maximum carbon conversion; $\mathrm{F}$ is the fraction of $\mathrm{CH} 4$ - $\mathrm{CO}_{2}$ in generated landfill gas (0.50); $16 / 12$ is the molecular weight ratio $\mathrm{CH}_{4} / \mathrm{C} ; 44 / 12$ is the molecular weight ratio $\mathrm{CO}_{2} / \mathrm{C}$; 0.60 is the gas collection efficiency rate and $1.132 \mathrm{~kg} \mathrm{~m}^{-3}$ is the biogas density.

5

Incineration: Energy from incineration is calculated using the Low Heating Value (LHV) of each of the waste fractions. LHV represents the usable heat released from waste and varies according to waste type (Demirbas, 2004). Energy from incineration is calculated using Eq. (S6).

$$
\mathrm{EI}=\mathrm{W}_{\mathrm{s}, \mathrm{j}} * \mathrm{LHV}_{\mathrm{j}} \quad \text { Eq. }(\mathrm{S} 6)
$$

10

Where: EI is energy gained from incineration; $\mathrm{W}_{\mathrm{s}, \mathrm{j}}$ is the amount of waste type $\mathrm{j}$ generated in sector $\mathrm{s}$ (municipal/industrial) going to incineration with energy recovery (municipal/industrial) and $\mathrm{LHV}_{\mathrm{j}}$ is the low heating value of waste typej.

Table S9 presents the different management options implemented for each waste type.

15

20 
Table S9. Solid waste management technologies

\begin{tabular}{|c|c|c|c|c|c|c|c|c|c|c|c|c|c|}
\hline \multirow[b]{2}{*}{ Solid waste management technology } & \multicolumn{8}{|c|}{ Municipal solid waste } & \multicolumn{5}{|c|}{ Industrial solid waste } \\
\hline & Food & Glass & Metal & Other & Paper & Plastic & Textile & Wood & Food & $\begin{array}{c}\text { Pulp and } \\
\text { paper }\end{array}$ & Rubber & Textile & Wood \\
\hline Open burned & $\mathrm{X}$ & & & $\mathrm{X}$ & $\mathrm{X}$ & $\mathrm{X}$ & $\mathrm{X}$ & $\mathrm{X}$ & $\mathrm{X}$ & $\mathrm{X}$ & $\mathrm{X}$ & $\mathrm{X}$ & $\mathrm{X}$ \\
\hline Scattered and/or disposed to water-courses & $\mathrm{X}$ & $\mathrm{X}$ & $\mathrm{X}$ & $\mathrm{X}$ & $\mathrm{X}$ & $\mathrm{X}$ & $\mathrm{X}$ & $\mathrm{X}$ & $\mathrm{X}$ & $\mathrm{X}$ & $\mathrm{X}$ & $\mathrm{X}$ & $\mathrm{X}$ \\
\hline $\begin{array}{l}\text { Unmanaged solid waste disposal site - low humidity } \\
-<5 \text { m deep }\end{array}$ & $\mathrm{X}$ & & & $X$ & $\mathrm{X}$ & & $X$ & $\mathrm{X}$ & $\mathrm{X}$ & $\mathrm{X}$ & & $\mathrm{X}$ & $\mathrm{X}$ \\
\hline $\begin{array}{l}\text { Unmanaged solid waste dis posal site - high } \\
\text { humidity - > 5m deep }\end{array}$ & $\mathrm{X}$ & & & $\mathrm{X}$ & $\mathrm{X}$ & & $\mathrm{X}$ & $\mathrm{X}$ & $\mathrm{X}$ & $X$ & & $X$ & $X$ \\
\hline Compacted landfill & $\mathrm{X}$ & $\mathrm{X}$ & $X$ & $X$ & $\mathrm{X}$ & $X$ & $X$ & $\mathrm{X}$ & $\mathrm{X}$ & $X$ & $\mathrm{X}$ & $\mathrm{X}$ & $\mathrm{X}$ \\
\hline Covered landfill & $\mathrm{X}$ & & & $X$ & $\mathrm{X}$ & & $X$ & $X$ & $\mathrm{X}$ & $X$ & & $\mathrm{X}$ & $\mathrm{X}$ \\
\hline Landfill gas recovery and flaring & $X$ & & & $X$ & $X$ & & $X$ & $\mathrm{X}$ & $X$ & $X$ & & $\mathrm{X}$ & $X$ \\
\hline Landfill gas recovery and used & $\mathrm{X}$ & & & $X$ & $\mathrm{X}$ & & $\mathrm{X}$ & $X$ & $\mathrm{X}$ & $\mathrm{X}$ & & $\mathrm{X}$ & $\mathrm{X}$ \\
\hline Low quality burning of waste & $X$ & & & $\mathrm{X}$ & $\mathrm{X}$ & $\mathrm{X}$ & $X$ & $\mathrm{X}$ & $\mathrm{X}$ & $\mathrm{X}$ & $\mathrm{X}$ & $\mathrm{X}$ & $\mathrm{X}$ \\
\hline Incineration (poor air quality controls) & $\mathrm{X}$ & & & $\mathrm{X}$ & $\mathrm{X}$ & $\mathrm{X}$ & $\mathrm{X}$ & $\mathrm{X}$ & $X$ & $\mathrm{X}$ & $\mathrm{X}$ & $\mathrm{X}$ & $\mathrm{X}$ \\
\hline $\begin{array}{l}\text { Incineration (high quality air pollution controls - } \\
\text { energy recovery) }\end{array}$ & $X$ & & & $X$ & $X$ & $X$ & $X$ & $X$ & $X$ & $X$ & $X$ & $X$ & $X$ \\
\hline Anaerobic digestion & $\mathrm{X}$ & & & & & & & & $\mathrm{X}$ & & & & \\
\hline Composting & $\mathrm{X}$ & & & & & & & & $\mathrm{X}$ & & & & \\
\hline Recycling & & $X$ & $X$ & & $X$ & $X$ & $X$ & $X$ & & & & & $X$ \\
\hline
\end{tabular}

\section{S2.2.2 Wastewater}

In order to quantify the organic content in industrial and municipal wastewater and its respective flows, the following approach

5 is used (calculations are carried out by country/region and year):

1. Quantification of BOD in untreated domestic wastewater and COD in untreated industrial wastewater using the IPCC method (based on IPCC, 2006, Volume 5, Chapter 6, Equation 6.4 and Equation 6.6 ).

2. Identification by country/region of the application rate of current (and future) use of wastewater management technologies/systems (EUROSTAT 2016, OECD 2016, UNFCCC CRF Tables 2016 and some official national documents). This study distinguishes various wastewater management options for each of the two wastewater types. A description of each option can be found in Table S10. The assessment of the organic material flows is then carried out applying Eq. (S7) and Eq. (S8) based on Höglund-Isaksson et al., 2015

$$
\mathrm{COD}=\mathrm{WW}_{\mathrm{i}} * \mathrm{P}_{\mathrm{i}} * \mathrm{COD}_{\mathrm{i}} * \mathrm{Appl}_{\mathrm{m}, \mathrm{i}} * 0.01 \quad \text { Eq. }(\mathrm{S} 7) \quad ; \quad \mathrm{BOD}=\mathrm{POP}_{\mathrm{i}} * \mathrm{BOD}_{\mathrm{i}} * \mathrm{Appl}_{\mathrm{m}, \mathrm{i}} * 0.01 \quad \text { Eq. (S8) }
$$

15

Where: COD is Chemical Oxygen Demand (organic degradable material) in industrial wastewater; $\mathrm{WW}_{\mathrm{i}}$ is the amount of wastewater generated per tonne of product in industrial sector $\mathrm{i}$; $\mathrm{P}_{\mathrm{i}}$ is amount of production product in sector $\mathrm{i}$; $\mathrm{COD}_{\mathrm{i}}$ is total organic degradable material content in the wastewater measured as COD in industrial sectors i, BOD is Biochemical Oxygen 
Demand (organic degradable material) in domestic wastewater; $\mathrm{POP}_{\mathrm{i}}$ is population; $\mathrm{BOD}_{\mathrm{i}}$ is per capita BOD (default values used from IPCC, 2006, Volume 5, Chapter 6, Table 6.4) and $\mathrm{Appl}_{\mathrm{m}, \mathrm{s}, \mathrm{j}}$ is the application of the wastewater treatment option $\mathrm{m}$ to treat domestic/industrial wastewater.

3. Estimation of the energy potential from domestic and industrial anaerobic wastewater with gas recovery. Volumes of biogas from industrial and domestic wastewater treatment are calculated by applying Eq. (S9)

$$
\text { BWWI }(B W W D)=\operatorname{COD}(B O D) * \operatorname{Appl}_{a t} * 0.01 *\left(1-\operatorname{Reff}_{\mathrm{pt}}\right) * \operatorname{Reff}_{\mathrm{at}} * \mathrm{~F}_{\mathrm{COD}}\left(\mathrm{F}_{\mathrm{BOD}}\right) * \mathrm{TCF} *(1-\mathrm{f}) * \mathrm{Y} \quad \text { Eq. (S9) }
$$

Where: BWWI is biogas generation from industrial $/ B W W D$ domestic wastewater treatment; COD is Chemical Oxygen

10 Demand, $B O D$ is Biochemical Oxygen Demand in domestic wastewater; Applat $_{\text {at }}$ is the application in \% of the anaerobic wastewater treatment to industrial/domestic sector $\mathrm{i}$; $\operatorname{Reff}_{\mathrm{pt}}$ is the COD/BOD removal efficiency primary treatment (before anaerobic treatment a primary removal of floating and settleable material is needed (Cakir and Stenstrom, 2005)); Reff ${ }_{\text {at }}$ is the $\mathrm{COD} / \mathrm{BOD}$ removal efficiency anaerobic treatment; $\mathrm{F}_{\mathrm{COD}}$ is the maximum $\mathrm{CH}_{4}$ production capacity per $\mathrm{Kg} \mathrm{COD} ; \mathrm{F}_{\mathrm{BOD}}$ is the maximum $\mathrm{CH}_{4}$ production capacity per Kg BOD, TCF is temperature correction factor (just for domestic wastewater)

15 (see Höglund-Isaksson et al., 2015. Section 3.4.2) $\mathrm{f}$ is the rate of $\mathrm{CH}_{4}$ solubility (depends on wastewater temperature (Liu et al., 2014) and $Y=0.35 \mathrm{~m}^{3}$ is the biogas yield per $\mathrm{Kg}$ COD removed, $0.84 \mathrm{~m}^{3}$ is the biogas yield per $\mathrm{Kg}$ BOD removed.

One of the challenges of wastewater treatment is the removal of nitrogen and phosphorus to avoid eutrophication of the water bodies. For that purpose, around 35\% of the COD in wastewater is needed for biological nitrogen removal (Hu et al., 2011) and hence unavailable for biogas generation. Therefore, an additional estimation of biogas generation representing the balance

20 between COD and nitrogen removal is also carried out. To compensate for the $35 \%$ of COD needed for the removal of nitrogen, estimations of biogas generation assuming that the primary sludge is anaerobically digested and partially converted into biogas is also performed for the MFR scenarios. This process is represented in Eq (S10) where (1- Reff $\mathrm{pt}_{\text {p }}$ representing the removal efficiency (35\%) of primary treatment is removed and a factor representing the 35\% COD demanded for nitrogen removal is added $\left(1-\mathrm{COD}_{\mathrm{N}}\right)$. However, this process does not add benefits in terms of biogas generation since the effect of adding the

25 COD of primary sludge is cancelled by the COD demanded for nitrogen removal.

$$
\text { BWWI }(B W W D)=\operatorname{COD}(B O D) * \operatorname{Appl}_{\mathrm{at}} * 0.01 * \operatorname{Reff}_{\mathrm{at}} *\left(1-\mathrm{COD}_{\mathrm{N}}\right) * \mathrm{~F}_{\mathrm{COD}}\left(\mathrm{F}_{\mathrm{BOD}}\right) * \mathrm{TCF} *(1-\mathrm{f}) * \mathrm{Y} \quad \text { Eq. }(\mathrm{S} 10)
$$


Table S10. Wastewater treatment technologies

\begin{tabular}{ccccccc}
\hline $\begin{array}{c}\text { Wastewater treatment } \\
\text { technology }\end{array}$ & Uncollected & $\begin{array}{c}\text { Dentralized } \\
\text { collection }\end{array}$ & $\begin{array}{c}\text { Decentralized } \\
\text { collection }\end{array}$ & Food & $\begin{array}{c}\text { Pulp and } \\
\text { paper }\end{array}$ & $\begin{array}{c}\text { Other } \\
\text { manufacturing } \\
\text { industry }\end{array}$ \\
\cline { 2 - 6 } Uncollected & $\mathrm{X}$ & $\mathrm{X}$ & $\mathrm{X}$ & $\mathrm{X}$ & $\mathrm{X}$ & $\mathrm{X}$ \\
Collected but untreated & & $\mathrm{X}$ & $\mathrm{X}$ & $\mathrm{X}$ & $\mathrm{X}$ & $\mathrm{X}$ \\
$\begin{array}{c}\text { Primary treatment } \\
\text { Aerobic treatment }\end{array}$ & $\mathrm{X}$ & & $\mathrm{X}$ & $\mathrm{X}$ & $\mathrm{X}$ \\
$\begin{array}{c}\text { Anaerobic secondary and/or } \\
\text { tertiary treatment without gas } \\
\text { recovery }\end{array}$ & $\mathrm{X}$ & $\mathrm{X}$ & $\mathrm{X}$ & $\mathrm{X}$ \\
$\begin{array}{c}\text { Anaerobic secondary and/or } \\
\text { tertiary treatment with gas } \\
\text { recovery }\end{array}$ & & & & & $\mathrm{X}$ & $\mathrm{X}$ \\
Latrine/ Septic tank & $\mathrm{X}$ & & & & $\mathrm{X}$ & $\mathrm{X}$ \\
\hline
\end{tabular}

\section{S2.3 Waste and wastewater management scenarios}

Description of the measures adopted in the different scenarios are presented below. Each scenario builds on the one before:

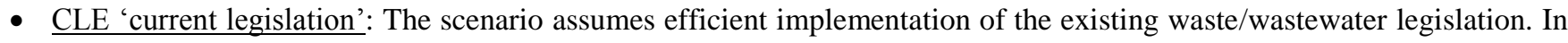
countries/regions where no waste legislation exists -CLE- represents the current waste management situation.

- MFR 'maximum technically feasible phase-in of waste and wastewater management': A scenario that assumes the implementation of the 'best available technology' to improve waste and wastewater management systems without regarding costs but considering constrains that could limit the applicability of certain technologies and assumes a phase-out of waste going to landfills, being dumped or openly burnt. Waste flows are redirected to recycling, treatment with energy recovery, or controlled incineration with energy recovery. The maximum recycling potential of waste streams are applied as follow: $90 \%$ of municipal paper and textile waste recycled by 2030 - 80\% of municipal plastic and wood waste recycled by 2030. $100 \%$ incineration of industrial solid waste by $2030,100 \%$ of food waste treated in anaerobic digesters with biogas recovery by 2050 and $100 \%$ of collected industrial and domestic wastewater treated in anaerobic processes by 2050 .

- $\mathrm{MFR}+\mathrm{PCY}+\mathrm{PLA}$ 'maximum technically feasible phase-in of waste and wastewater management' + 'policy implementation + 'plastic incineration': The scenario adopts the MFR + policies for reducing the generation of food and plastic municipal solid waste + maintains current municipal plastic waste recycling rates and sends excess plastics to incineration for energy recovery to represent the current recycling market plastic situation. The policies are assumed to 
reach a maximum municipal food waste rate reduction of 50\% by the year 2030 based on Lipinski et al., 2013 and based on the target adopted by the United Nations Assembly in 2015 of halving per capita food waste at the retail and consumer level as a part of the 2030 Sustainable Development Goals and a maximum municipal plastic waste rate reduction of $50 \%$ by the year 2030 as a part of the 2030 Sustainable Development Goals.

- $\mathrm{MFR}+\mathrm{PCY}+\mathrm{REC}$ 'maximum technically feasible phase-in of waste and wastewater management' + 'policy implementation' + 'maximum recycling capacity': This scenario adopts the MFR + PCY + reaches the maximum possible recycling capacity for all waste streams (including plastic). For wastewater, the scenario includes a capacity to increase the collection (reaching 100\%) and treatment of wastewater in urban areas.

- $\mathrm{MFR}+\mathrm{PCY}+\mathrm{REC}+\mathrm{IMP}$ 'maximum technically feasible phase-in of waste/wastewater management' + 'policy implementation' + 'maximum recycling capacity' + 'technology efficiency improvement': This scenario adopts the MFR $+\mathrm{PCY}+\mathrm{REC}+$ technological development to increase biogas yield formation and to reduce losses during the treatment processes for both solid waste and wastewater. Improvements include e.g. adding accelerants (biological or chemical) to improve the metabolic conditions for microorganism growth and therefore biogas formation (Mao et al., 2015), recovery of the dissolved methane in wastewater, improvement of the biogas recovery rates. For incineration, improvements include an increase of the Low Heating Value (LHV), increase in the efficiency of input/air flow and reduction of energy losses during the process.

\section{S2.4 Limitations and uncertainty of the waste and wastewater management scenarios}

In this study, anaerobic digestion of waste and anaerobic wastewater treatment are analysed independent of the type of anaerobic reactor e.g. Anaerobic Sludge Blanket (UASB), CSTR and Anaerobic filter (AF-Fixed film) (Barber and Stuckey,

20 1999). Different reactors involve different flow modes, retention times and organic load rates, which are all factors that affect the efficiency of biogas formation (Mao et al., 2015). Furthermore, default IPCC values for biogas rate formation under average normal operating conditions are used to estimate biogas generation. However, it is well known that the microbial community is extremely sensitive and if not properly managed the process would be affected resulting in reduced biogas production (Munk Bernhard et al., 2010).

25 Regarding incineration and waste heating values a similar situation to the anaerobic treatment is present; incineration is treated as a general technology independent of the type of incinerator. In addition, although a specific Low Heating Value (LHV) is used for each waste fraction, the variability between regions/countries was not taken into account due to a lack of regional data. In general, the scenarios presented do not take into account the losses of substrates during transport and handling, which may result in a lower substrate input actually going into the treatment facilities.

30 Given the global scope and the wide range of different types of input data going into estimations, it is unavoidable that a certain degree of uncertainty is present in the results. E.g., for developing countries, a lack of country-specific data on quantities of waste and wastewater, implemented treatment modes, and current energy/biogas recovery rates, has been bridged by using default assumptions adapted from neighbouring countries or regions. 


\section{Results by major world regions}

\subsection{Carbon content and flows in solid waste}
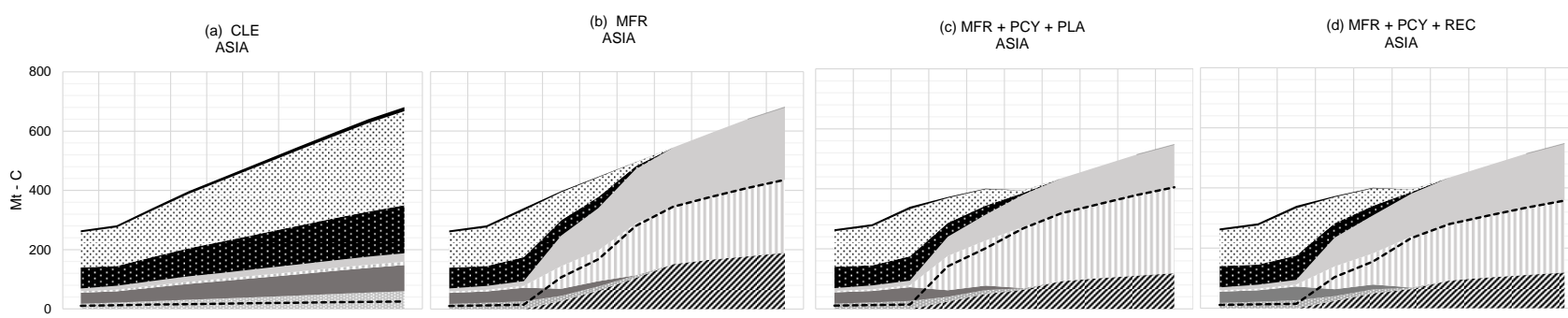

LAC

LAC

LAC

LAC

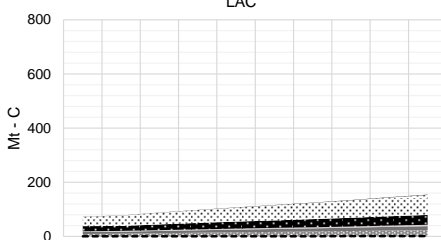

MAF

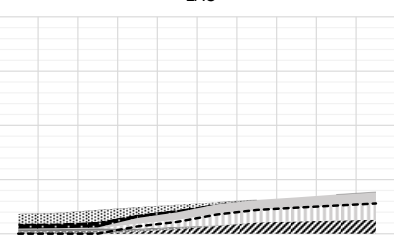

MAF
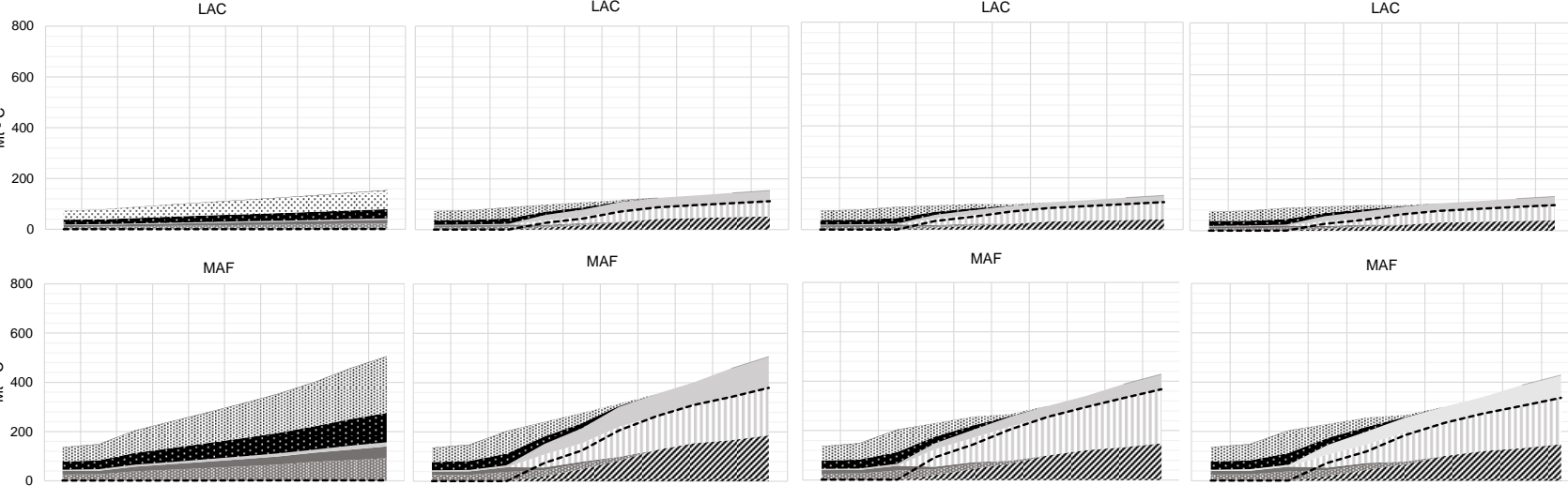

UECL

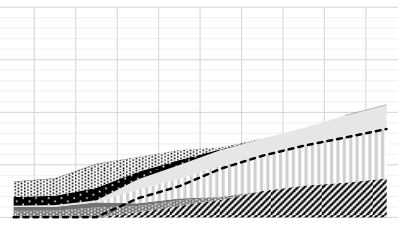

$\mathrm{OECD}$

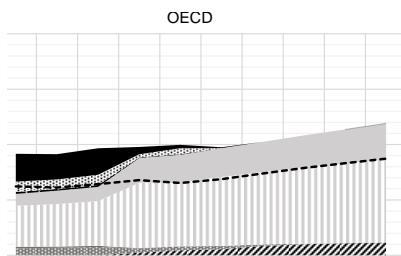

REF

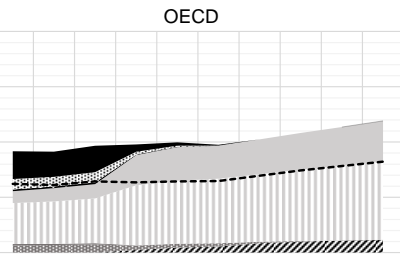

REF

REF
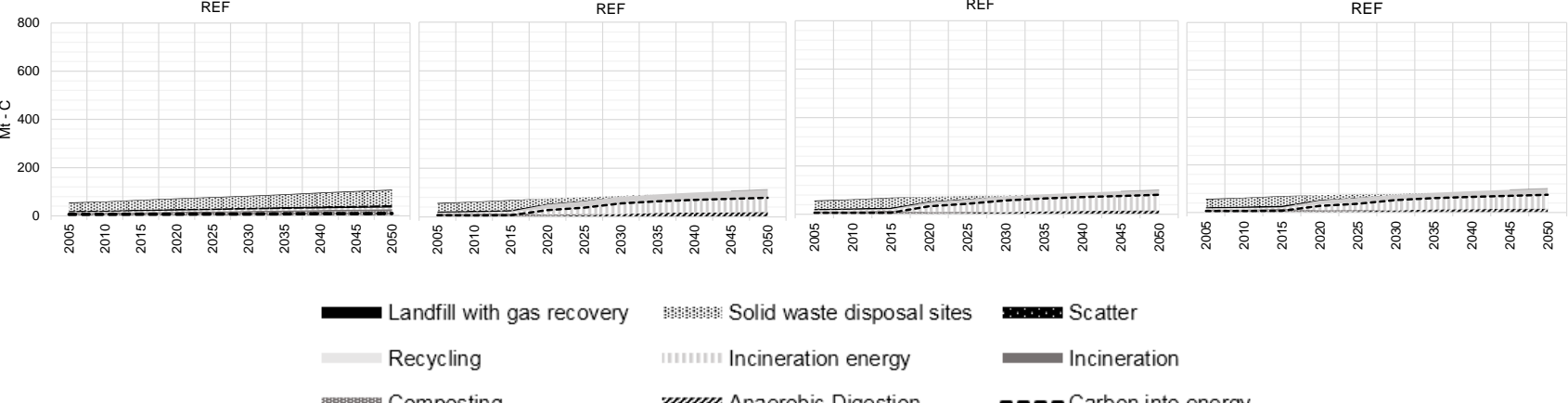

яв

mrrmm Anaerobic Digestion

Incineration

- - - Carbon into energy

Fig. S2. Carbon flows - solid waste by region 


\subsection{BOD and COD flows in wastewater}

(a) CLE

ASIA

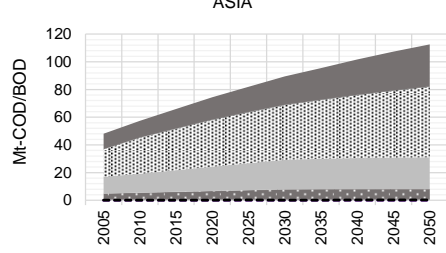

LAC

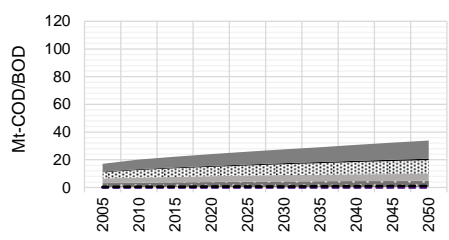

MAF

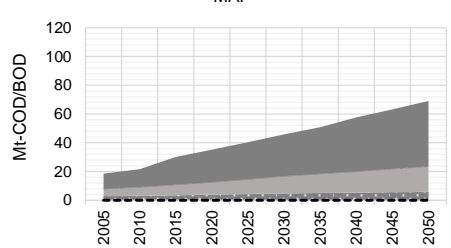

OECD

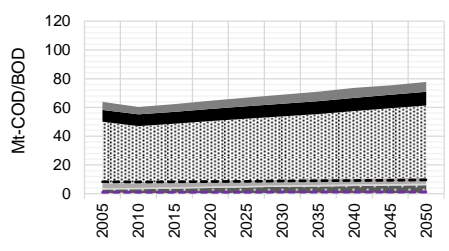

REF

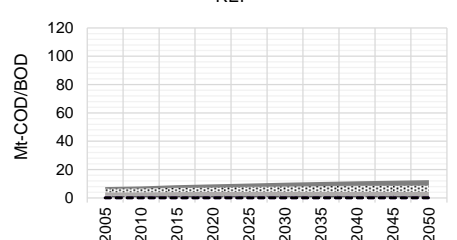

(b) MFR

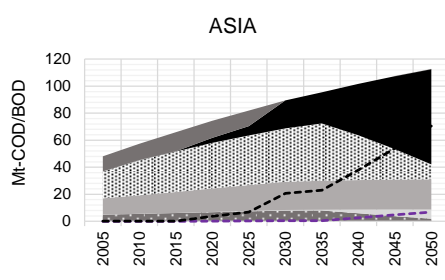

LAC

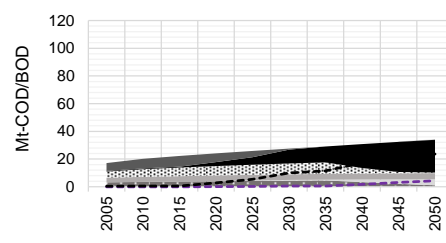

MAF

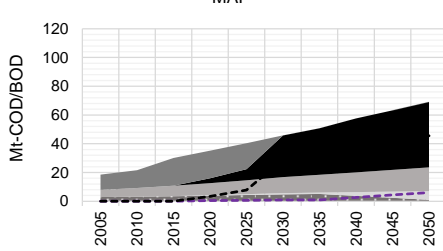

OECD

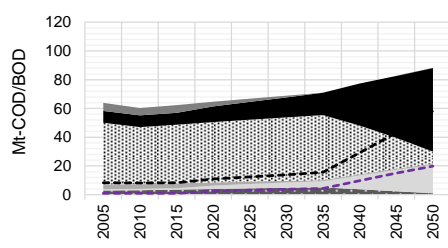

REF

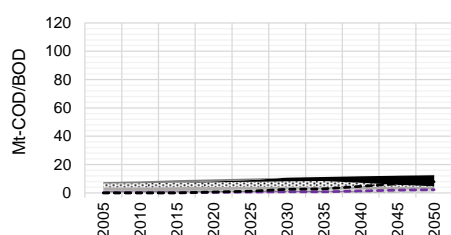

(c) $\mathrm{MFR}+\mathrm{PCY}$
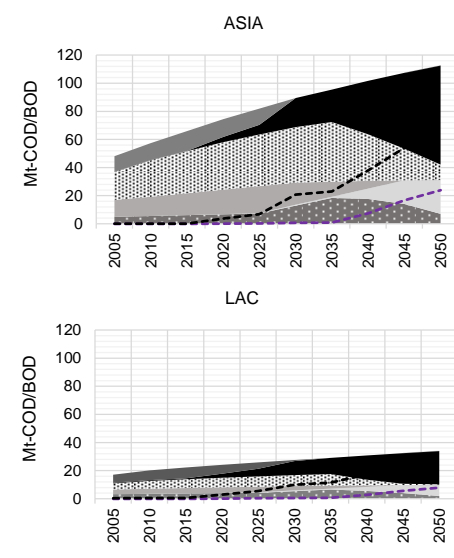

MAF

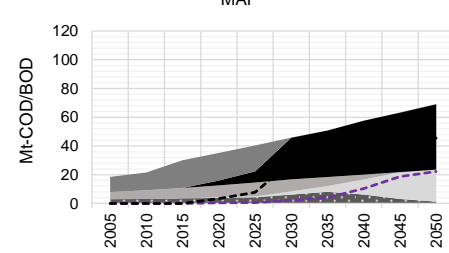

OECD

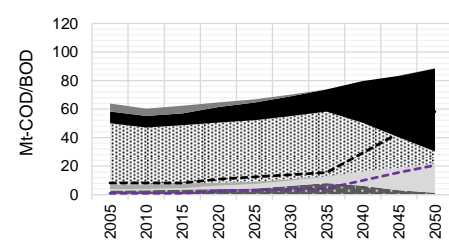

REF

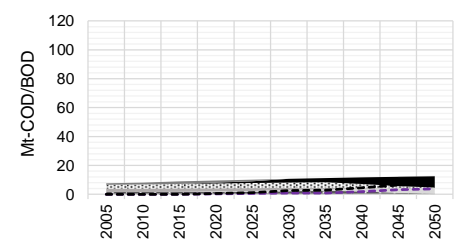

[COD] Other wastewater treatment without energy recovery (no treatment, primary, anaerobic-no

[COD] Anaerobic treatment with gas recovery, upgrading and use

awalan: [COD] Aerobic treatment

$[B O D]$ Other wastewater treatment without energy recovery (no treatment, primary, anaerobic-no

energy recovery)
[BOD] Anaerobic treatment with gas recovery, upgrading and use

$[B O D]$ Aerobic treatment

----[BOD] into energy

----[COD] into energy

Fig. S3. BOD and COD flows by region 
3.3 Maximum energy potential from waste and wastewater
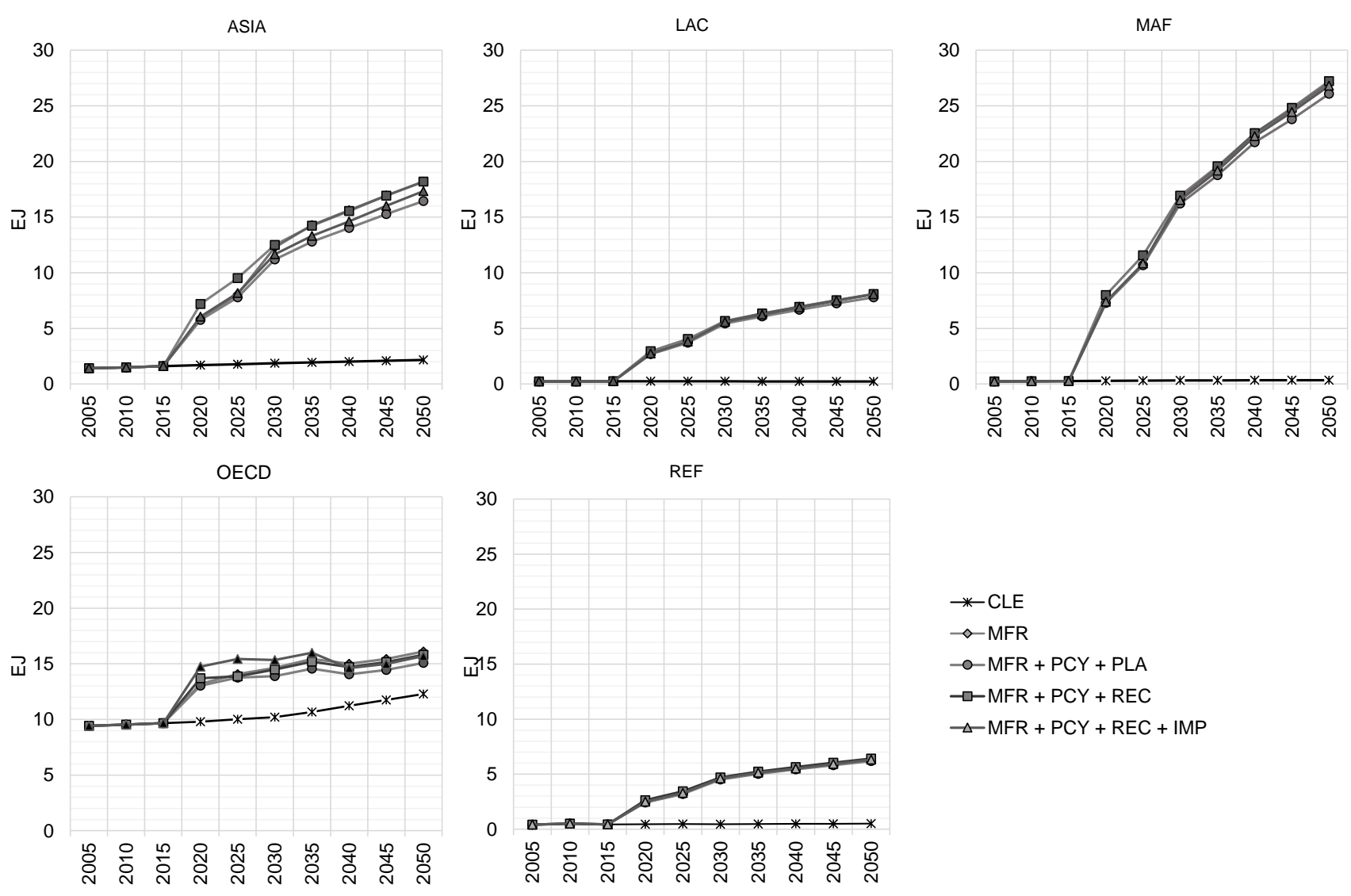

Fig. S4. Maximum energy potential from waste and wastewater by region 


\section{References}

Alavi Moghadam, M. R., Mokhtarani, N. and Mokhtarani, B.: Municipal solid waste management in Rasht City, Iran, Waste Management, 29(1), 485-489, doi:10.1016/j.wasman.2008.02.029, 2009.

Anon: Waste data base of Bangladesh, 2009.

5 Arzumanyan, G.: Municipal Solid Waste Management in Armenia. Current Trends and Steps Forward, Lund University, Sweeden., 2014.

Asase, M., Yanful, E. K., Mensah, M., Stanford, J. and Amponsah, S.: Comparison of municipal solid waste management systems in Canada and Ghana: A case study of the cities of London, Ontario, and Kumasi, Ghana, Waste Management, 29(10), 2779-2786, doi:10.1016/j.wasman.2009.06.019, 2009.

10 Bai, R. and Sutanto, M.: The practice and challenges of solid waste management in Singapore, Waste Management, 22(5), 557-567, doi:10.1016/S0956-053X(02)00014-4, 2002.

Barber, W. P. and Stuckey, D. C.: The use of the anaerobic baffled reactor (ABR) for wastewater treatment: a review, Water Research, 33(7), 1559-1578, doi:10.1016/S0043-1354(98)00371-6, 1999.

Bello, I., Norshafiq bin Ismail, M. and Kabbashi, N.: Solid Waste Management in Africa: A Review., 2016.

15 Bhuiyan, S. H.: A crisis in governance: Urban solid waste management in Bangladesh, Habitat International, 34(1), 125-133, doi:10.1016/j.habitatint.2009.08.002, 2010.

Bo-Feng, C., Jian-Guo, L., Qing-Xian, G., Xiao-Qin, N., Dong, C., Lan-Cui, L., Ying, Z. and Zhan-Sheng, Z.: Estimation of Methane Emissions from Municipal Solid Waste Landfills in China Based on Point Emission Sources, Advances in Climate Change Research, 5(2), 81-91, doi:10.3724/SP.J.1248.2014.081, 2014.

20 Bräutigam, K.-R. and Gonzalez, T.: Evaluation of Municipal Solid Waste Management in Santiago de Chile Regarding Sustainability, n.d.

Budhiarta, I., Siwar, C. and Basri, H.: Current status of municipal solid waste generation in Malaysia, International Journal of Advanced Science Engineering Information Technology, 2(2088-5334), 2012.

Burnley, S. J.: A review of municipal solid waste composition in the United Kingdom, Waste Management, 27(10), 12741285, doi:10.1016/j.wasman.2006.06.018, 2007.

Cakir, F. Y. and Stenstrom, M. K.: Greenhouse gas production: A comparison between aerobic and anaerobic wastewater treatment technology, Water Research, 39(17), 4197-4203, doi:10.1016/j.watres.2005.07.042, 2005.

Castagnari, E.: Municipal Solid Waste in Brazil: Conditions, Problems and Solutions, 2005.

Chieueh, P.-T. and Yu, Y.-H.: Assessment on the solid waste management information system in Taiwan., Journal environmental engineering landscape management, 16(6), 427-433, 2006.

China Statistical Yearbook: China Statistical Yearbook 2001-2007, 2007.

Consonni, S. and Viganò, F.: Material and energy recovery in integrated waste management systems: The potential for energy recovery, Waste Management, 31(9), 2074-2084, doi:10.1016/j.wasman.2011.05.013, 2011. 
Cvetkovska, M. and Rushiti, A.: Municipal waste management in the Former Yugoslav Republic of Macedonia, European Environment Agency., 2013.

Damanhuri, E., Wahyu, I. M., Ramang, R. and Padmi, T.: Evaluation of municipal solid waste flow in the Bandung metropolitan area, Indonesia, Journal of Material Cycles and Waste Management, 11(3), 270-276, doi:10.1007/s10163-0090241-9, 2009.

Damghani, A. M., Savarypour, G., Zand, E. and Deihimfard, R.: Municipal solid waste management in Tehran: Current practices, opportunities and challenges, Waste Management, 28(5), 929-934, doi:10.1016/j.wasman.2007.06.010, 2008.

Daskalopoulos, E., Badr, O. and Probert, S. D.: Municipal solid waste: a prediction methodology for the generation rate and composition in the European Union countries and the United States of America, Resources, Conservation and Recycling, 24(2), 155-166, doi:10.1016/S0921-3449(98)00032-9, 1998.

Demirbas, A.: Combustion characteristics of different biomass fuels, Progress in Energy and Combustion Science, 30(2), 219230, doi:10.1016/j.pecs.2003.10.004, 2004.

Demirbas, A., Edris, G. and Alalayah, W. M.: Sludge production from municipal wastewater treatment in sewage treatment plant, Energy Sources, Part A: Recovery, Utilization, and Environmental Effects, 39(10), 999-1006, 15 doi:10.1080/15567036.2017.1283551, 2017.

Department of Environmental Affairs: National waste information baseline report South Africa, 2012.

EUROSTAT database. http://epp.eurostat.ec.europa.eu/, European Commission, Brussels, 2016.

EUROSTAT database. http://epp.eurostat.ec.europa.eu/, European Commission, Brussels, 2017.

FAOSTAT: http://faostat.fao.org, Food and Agriculture Organization, Rome, 2016.

20 EPA: Municipal solid waste generation, recycling, and disposal in the United States: Facts and Figures for 2012, 2012.

Forouhar, A. and Hristovski, K. D.: Characterization of the municipal solid waste stream in Kabul, Afghanistan, Habitat International, 36(3), 406-413, doi:10.1016/j.habitatint.2011.12.024, 2012.

Gomez, G., Meneses, M., Ballinas, L. and Castells, F.: Characterization of urban solid waste in Chihuahua, Mexico, Waste Management, 28(12), 2465-2471, doi:10.1016/j.wasman.2007.10.023, 2008.

25 Gonzalez, G. L.: Residuos sólidos urbanos Argentina. tratamiento y disposición final situación actual alternativas futuras., 2010.

Hikkaduwa, H. ., Gunawardana, K. W., Halwatura, R. and Hyoung, Y.: Sustainable Approaches to the Municipal Solid Waste Management in Sri Lanka, SECM, andy, Sri Lanka., 2015.

Höglund-Isaksson, L: GAINS model review of potentials and cost for reducing methane emissions from EU agriculture,

IIASA, Laxenburg, Austria., 2015.

Höglund-Isaksson, L.: Global anthropogenic methane emissions 2005-2030: technical mitigation potentials and costs, Atmospheric Chemistry and Physics, 12(19), 9079-9096, 2012. 
Höglund-Isaksson, L., Winiwarter, W., Purohit, P. and Gómez-Sanabria: Non-CO2 greenhouse gas emissions, mitigation potentials and costs in the EU-28 from 2005 to 2050, 2015.

Hoornweg, D. and Bhada-Tata, P.: What a waste. A global review of solid waste management, Urban development series knowledge papers, The World Bank., 2012.

5 Hsiao, C.: Analysis of Panel Data, Cambrige University Press., New Yotk., 1986.

Hu, Z., Houweling, D. and Dold, P.: Biological nutrient removal in municipal wastewater treatment: new directions in sustainability, Journal of Environmental Engineering, 138(3), 307-317, 2011.

IEA: Economic sustainability of manure based centralized co-digestion, Bioenergy Task 37., 2014.

Instituto Nacional de Estadística: Generación y manejo de residuos y desechos sólidos en Venezuela, 2011 - 2012, 2012.

10 International Finance Corporation: Municipal Solid Waste Management: Opportunities for Ukraine. Summary of Key findings., 2010.

IPCC: IPCC Guidelines for National Greenhouse Gas Inventories 2006., 2006.

ISWA: State of the Nation Report. Landfilling Practices and Regulation in New Zealand., 2011.

Johnstone, N. and Labonne, J.: Generation of household solid waste in OECD countries: an empirical analysis using 15 macroeconomic data, Land Economics, 80(4), 529-538, 2004.

Karellas, S., Boukis, I. and Kontopoulos, G.: Development of an investment decision tool for biogas production from agricultural waste, Renewable and Sustainable Energy Reviews, 14(4), 1273-1282, doi:10.1016/j.rser.2009.12.002, 2010.

Karunarathne, L.: Municipal Solid Waste Management (MSWM) in Sri Lanka., 2015.

Kigozi, R., Aboyade, A. and MUZENDA, E.: Biogas Production Using the Organic Fraction of Municipal Solid Waste as 20 Feedstock., 2014.

Kumar, S., Bhattacharyya, J. K., Vaidya, A. N., Chakrabarti, T., Devotta, S. and Akolkar, A. B.: Assessment of the status of municipal solid waste management in metro cities, state capitals, class I cities, and class II towns in India: An insight, Waste Management, 29(2), 883-895, doi:10.1016/j.wasman.2008.04.011, 2009.

Larochelle, L., Turner, M. and LaGiglia, M.: Evaluation of NAMA opportunities in Colombia's solid waste sector, 2012.

25 Lebersorger, S. and Beigl, P.: Municipal solid waste generation in municipalities: Quantifying impacts of household structure, commercial waste and domestic fuel, Waste Management, 31(9-10), 1907-1915, doi:10.1016/j.wasman.2011.05.016, 2011.

Lipinski, B., Hanson, C., Lomax, J., Kitinoja, L., Waite, R. and Searchinger, W.: Reducing food loss and waste, Working paper, World Resources Institute and UNEP., 2013.

Liu, Z., Yin, H., Dang, Z. and Liu, Y.: Dissolved Methane: A Hurdle for Anaerobic Treatment of Municipal Wastewater, 30 Environ. Sci. Technol., 48(2), 889-890, doi:10.1021/es405553j, 2014.

M. Sim, N., Wilson, D., Velis, C. and R. Smith, S.: Waste management and recycling in the former Soviet Union: The City of Bishkek, Kyrgyz Republic (Kyrgyzstan)., 2013. 
Mahar, A., Naseem, R., Qadir, A., Ahmed, T., Khan, Z. and Ali, M.: Review and Analysis of Current Solid Waste Management Situation in Urban Areas of Pakistan, in Proceedings of the International Conference on Sustainable Solid Waste Management, Chennai, India., 2007.

Manaf, L. A., Samah, M. A. A. and Zukki, N. I. M.: Municipal solid waste management in Malaysia: Practices and challenges, 5 Waste Management, 29(11), 2902-2906, doi:10.1016/j.wasman.2008.07.015, 2009.

Mao, C., Feng, Y., Wang, X. and Ren, G.: Review on research achievements of biogas from anaerobic digestion, Renewable and Sustainable Energy Reviews, 45, 540-555, doi:10.1016/j.rser.2015.02.032, 2015.

Martínez, J. A.: Use and valorization of organic fraction of municipal Solid waste in Colombia for sustainable development, Revista Ontare, 1(2), 243-254, 2015.

10 Mazzanti, M. and Nicolli, F.: Waste dynamics, decoupling and ex post policy effectiveness: evidence from the EU15, International Journal of Global Environmental Issues, 11(1), 61-78, 2011.

Mazzanti, M. and Zoboli, R.: Waste generation, waste disposal and policy effectiveness: Evidence on decoupling from the European Union, Resources, Conservation and Recycling, 52(10), 1221-1234, doi:10.1016/j.resconrec.2008.07.003, 2008.

Mazzanti, M. and Zoboli, R.: Municipal Waste Kuznets Curves: Evidence on Socio-Economic Drivers and Policy 15 Effectiveness from the EU, Environmental and Resource Economics, 44(2), 203-230, doi:10.1007/s10640-009-9280-x, 2009.

Meidiana, C. and Gamse, T.: Development of waste management practices in Indonesia, European journal of scientific research, 40(2), 199-210, 2010.

de Mes, T. Z. ., Stams, A. J. M., Reith, J. H. and Zeeman, G.: Methane production by anaerobic digestion of wastewater and solid wastes in Bio-methane \& Bio-hydrogen. Status and perspectives of biological methane and hydrogen production., 2003.

20 Ministry of Environment PNH: Solid Waste Management of Cambodia, 2010.

Ministry of environmental protection: Israel's waste revolution, 2012.

Ministry of the Environment: History and current state of waste management in Japan, 2012.

Mongtoeun, Y.: Analysis of Waste Generation and Recycling Potential for Development of 3R-based Solid Waste Management in Phnom Penh, Cambodia, Graduate School of Environmental and Life Science, Okayama University, Japan., 2015.

Munk Bernhard, Bauer Christoph, Gronauer Andreas and Lebuhn Michael: Population dynamics of methanogens during acidification of biogas fermenters fed with maize silage, Engineering in Life Sciences, 10(6), 496-508, doi:10.1002/elsc.201000056, 2010.

Nguyen, T.: Solid Waste Management in Vietnam, 2005.

30 Noukeu, N. A., Gouado, I., Priso, R. J., Ndongo, D., Taffouo, V. D., Dibong, S. D. and Ekodeck, G. E.: Characterization of effluent from food processing industries and stillage treatment trial with Eichhornia crassipes (Mart.) and Panicum maximum (Jacq.), Water Resources and Industry, 16, 1-18, doi:10.1016/j.wri.2016.07.001, 2016. 
OECD. Statistical Database. Organisation for Economic Co-operation and Development (OECD), Paris (See:http://stats.oecd.org/), retrieved 2016.

Okot-Okumu, J.: Solid waste management in African cities - East Africa, in Waste Management - An integrated vision., 2012.

5 Organización Panamericana de la Salud: Análisis sectorial de residuos sólidos in Paraguay, 2001.

Parrot, L., Sotamenou, J. and Dia, B. K.: Municipal solid waste management in Africa: Strategies and livelihoods in Yaoundé, Cameroon, Waste Management, 29(2), 986-995, doi:10.1016/j.wasman.2008.05.005, 2009.

Pasang, H., Moore, G. A. and Sitorus, G.: Neighbourhood-based waste management: A solution for solid waste problems in Jakarta, Indonesia, Waste Management, 27(12), 1924-1938, doi:10.1016/j.wasman.2006.09.010, 2007.

10 Penjor, Y.: Enhancing municipal solid waste management with 3R options in Thimphu, Buthan, Australian National University, Camberra, Australia., 2007.

Ryu, C.: Potential of Municipal Solid Waste for Renewable Energy Production and Reduction of Greenhouse Gas Emissions in South Korea, Journal of the Air \& Waste Management Association, 60(2), 176-183, doi:10.3155/1047-3289.60.2.176, 2010.

Sang-Arun, J. and Pasomsouk, K.: A guide for improving municipal solid waste management and promoting urban organic 15 waste utilization in Lao PDR, Institute for Global Environmental Strategies (IGES)., 2012.

Savino, A. A.: Diagnóstico de la situación del manejo de los Residuos Sólidos Municipales y Peligrosos en Argentina, 1999.

Sharholy, M., Ahmad, K., Mahmood, G. and Trivedi, R. C.: Municipal solid waste management in Indian cities - A review, Waste Management, 28(2), 459-467, doi:10.1016/j.wasman.2007.02.008, 2008.

SWEEPNET: Regional profile on the solid waste management situation in Middle East and North Africa, 2012.

20 Thang, D. N.: Improving Solid Waste Management for environmentally sustainable cities in Vietnam: Opportunities and challen ges, 2011.

Tsai, W. T. and Chou, Y. H.: An overview of renewable energy utilization from municipal solid waste (MSW) incineration in Taiwan, Renewable and Sustainable Energy Reviews, 10(5), 491-502, doi:10.1016/j.rser.2004.09.006, 2006.

UNFCCC (2016), "National Inventory Submissions 2016." Retrieved 2017, from https://unfccc.int/process/transparency-and-

25 reporting/reporting-and-review-under-the-convention/greenhouse-gas-inventories/submissions-of-annual-greenhouse-gasinventories-for-2017/submissions-of-annual-ghg-inventories-2016

Viceministerio de agua potable: Gestión de residuos sólidos peligrosos y residuos sólidos especiales, 2012.

Wang, H. and Nie, Y.: Municipal solid waste characteristics and management in China., J Air Waste Manag Assoc, 51(2), 30 250-263, 2001.

Wiedinmyer, C., Yokelson, R. J. and Gullett, B. K.: Global Emissions of Trace Gases, Particulate Matter, and Hazardous Air Pollutants from Open Burning of Domestic Waste, Environ. Sci. Technol., 48(16), 9523-9530, doi:10.1021/es502250z, 2014. 
Zakir Hossain, H. M., Hasna Hossain, Q., Uddin Monir, M. M. and Ahmed, M. T.: Municipal solid waste (MSW) as a source of renewable energy in Bangladesh: Revisited, Renewable and Sustainable Energy Reviews, 39, 35-41, doi:10.1016/j.rser.2014.07.007, 2014. 